\title{
Studies of the Fecundity of Sind Sardine fish, Sardinella sindensis (Day, 1878) (Family: Clupeidae), from Karachi coast, Pakistan.
}

\author{
${ }^{1}$ Amtyaz $*,{ }^{2}$ M. Atiqullah Khan, ${ }^{2}$ M. Zaheer Khan, ${ }^{3}$ M. Usman Ali Hashmi \\ ${ }^{1}$ Dept. of Zoology, Sir Syed Govt. Girls College NazimAbad, Karachi-74600, PAKISTAN. Cell No. 0092-3212374804 \\ ${ }^{2}$ Dept. of Zoology, University of Karachi, 75270, PAKISTAN \\ ${ }^{3}$ Dept. of Zoology, Dehli Govt. Science College, Hussainabad, 75950, Karachi, PAKISTAN \\ *Corresponding author E-mail:imtiazsafi76@gmail.com
}

\begin{abstract}
Sardinella sindensis is one of the dominant small pelagic fish of Karachi coast of Pakistan. Investigation on fecundity of sind sardinella was studied from January 2001 to April 2002. A total of 37 ovaries were examined of stages IV-VI (when not running). Mean fecundity ranged from 47521 to 110876 eggs. Log-log relationship between fecundity with total body-length, fish-weight \& ovary weight were correlated. Therefore it may be mentioned that the fecundity is generally proportional to the size of the ovary, which in turn is related to the size of the fish. The mean number of ova/g body weight and mean number of ova/g ovary weight were found to be 2425.250 and 9537.855 respectively. The gonads were two lobed; the left lobe was more fecund than the right one.
\end{abstract}

Keywords: Sardinella sindensis, Fecundity, Karachi coast.

\section{Introduction}

Sardinella sindensis is a small and common Sardine species of Sind, Pakistan. The Sind sardinella lives in the pelagicneritic coasts of Sea in the depth range of 0 - $50 \mathrm{~m}$. It is distributed in Western Indian Ocean: Arabian Sea, from Gulf of Aden to the Persian Gulf and Bombay. A clear knowledge of the fecundity of fishes is an essential pre-requisite in any program of fishery research and management policies [1]. In the group of Sardines, S. sindensis is economically important in the coast of Karachi. S. sindensis is commonly called Chacko, has widely used by poor families. In present study fecundity is defined as the number of oocytes at the stages IV-VI (when not running) before spawning. Different scientists like: $[2,3,4,5,6,7,8,9$, and 10] worked out on the fecundity of different marine fish species. Prior Information on different sardines species are also availables like: [11, 1, 12, 13,]. There is paucity of information on the study of reproductive biology of the Sardinella sindensis in the Karachi coast. The reproductive biology of Sardinella sindensis has not been widely reported in literature. The aim of this study was to investigate the fecundity which is an important aspect of the reproductive biology. It is hoped that the information obtained from this study will contribute to our knowledge of the reproductive biology of Sardinella sindensis and will be useful for fisheries and aquaculture production.

\section{Materials and methods}

A total of 417 fishes of $S$. sindensis were randomly sampled at fortnightly intervals from the commercial landings at korangi creek and west wharf fish harbour Karachi, during the period of Jan, 2001 - April 2002. The fish was identified by using the [14, 15] (FAO fish identification manuals). Simple random sampling technique was used [16]. All fishes were kept frozen until required length and weight of each sample were recorded. Gonads were dissected out and measured, and after that preserved in $10 \%$ formalin to hardening of ova for fecundity. The estimated total number of eggs were obtained weighting and counting 2 - 3 small sample, Three samples of ova 0.4 gm known weight, each (with ovarian tissue) were taken from the anteriorly, middle, and posterior parts for estimating fecundity, relative fecundity for number of eggs per gram of fish weight was also calculated. 
Table 1: Mean Fecundity Counts at various length ranges in S.sindensis

\begin{tabular}{cccccccc}
\hline Freq. & Lth. Range. & $\begin{array}{c}\text { Mean. } \\
\text { Length of } \\
\text { Fish(mm) }\end{array}$ & $\begin{array}{c}\text { Mean Wt. } \\
\text { of Fish(g) }\end{array}$ & $\begin{array}{c}\text { Mean Wt. of } \\
\text { Ovary. }(\mathrm{g})\end{array}$ & $\begin{array}{c}\text { Mean NO. of } \\
\text { Ova. }\end{array}$ & $\begin{array}{c}\text { NO. of Ova/gm. Wt. } \\
\text { Of Body. }\end{array}$ & $\begin{array}{c}\text { NO. of Ova/W } \\
\text { T. of Ovary. }\end{array}$ \\
\hline 02 & $17-17.4$ & 17.2 & 47.9 & 5.2 & 50331 & 1005.339 & 9707.899 \\
01 & $17.5-17.9$ & 17.6 & 49.2 & 5.2 & 47521 & 9650.874 & 9138.653 \\
09 & $18.0-18.4$ & 18.1 & 51.0 & 5.6 & 51480 & 1010.152 & 8197.682 \\
07 & $18.5-18.9$ & 18.6 & 56.5 & 6.6 & 48795 & 1133.249 & 8351.333 \\
09 & $19.0-19.4$ & 19.1 & 63.6 & 8.4 & 64895 & 1020.97 & 8729.375 \\
07 & $19.5-19.9$ & 19.6 & 73.0 & 8.0 & 89160 & 1791.179 & 11144.869 \\
02 & $20.0-20.4$ & 20.0 & 81.2 & 9.6 & 110876 & 1364.9898 & 11495.179 \\
37 & $17-20.4$ & 18.6 & 60.342 & 6.8 & 66151.142 & 2425.250 & 9537.855 \\
\hline
\end{tabular}

FECUNDITY=LENGTH S.sindensis.

$\log ($ Log Fecundit $)=0.539459+1.36961 \log ($ Log length 0$)$

$S=0.0068474 \quad R-S q=77.0 \% \quad R-S q(\operatorname{adj})=72.4 \%$

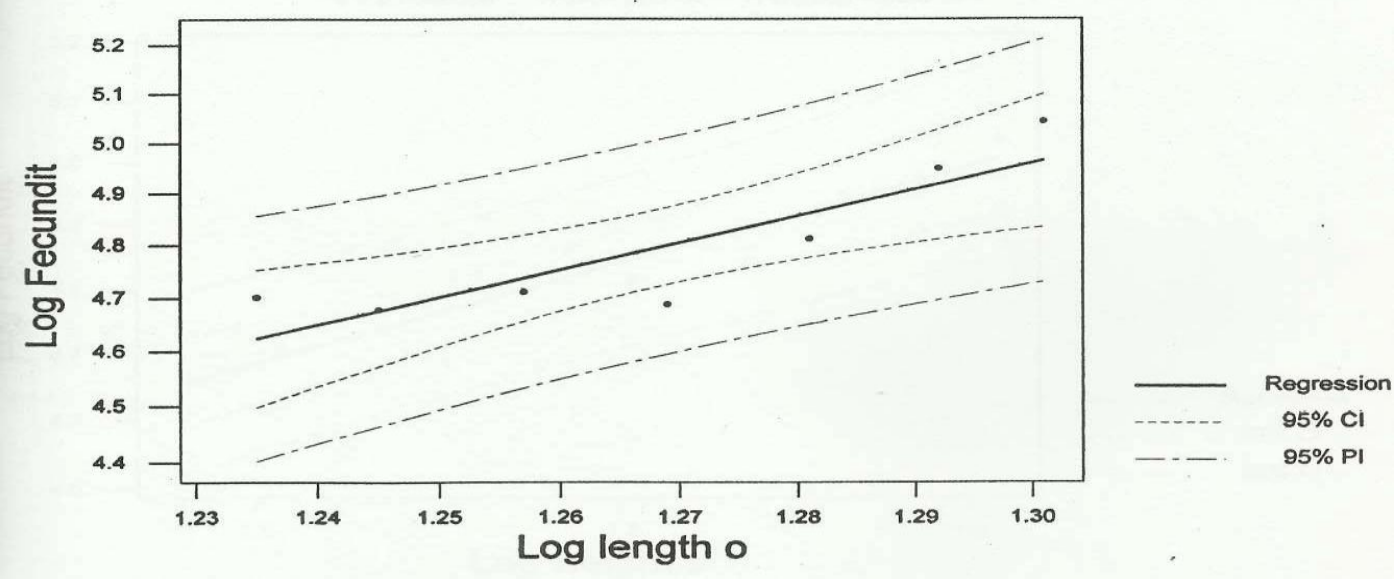

Fig.1: $\log$ of body length

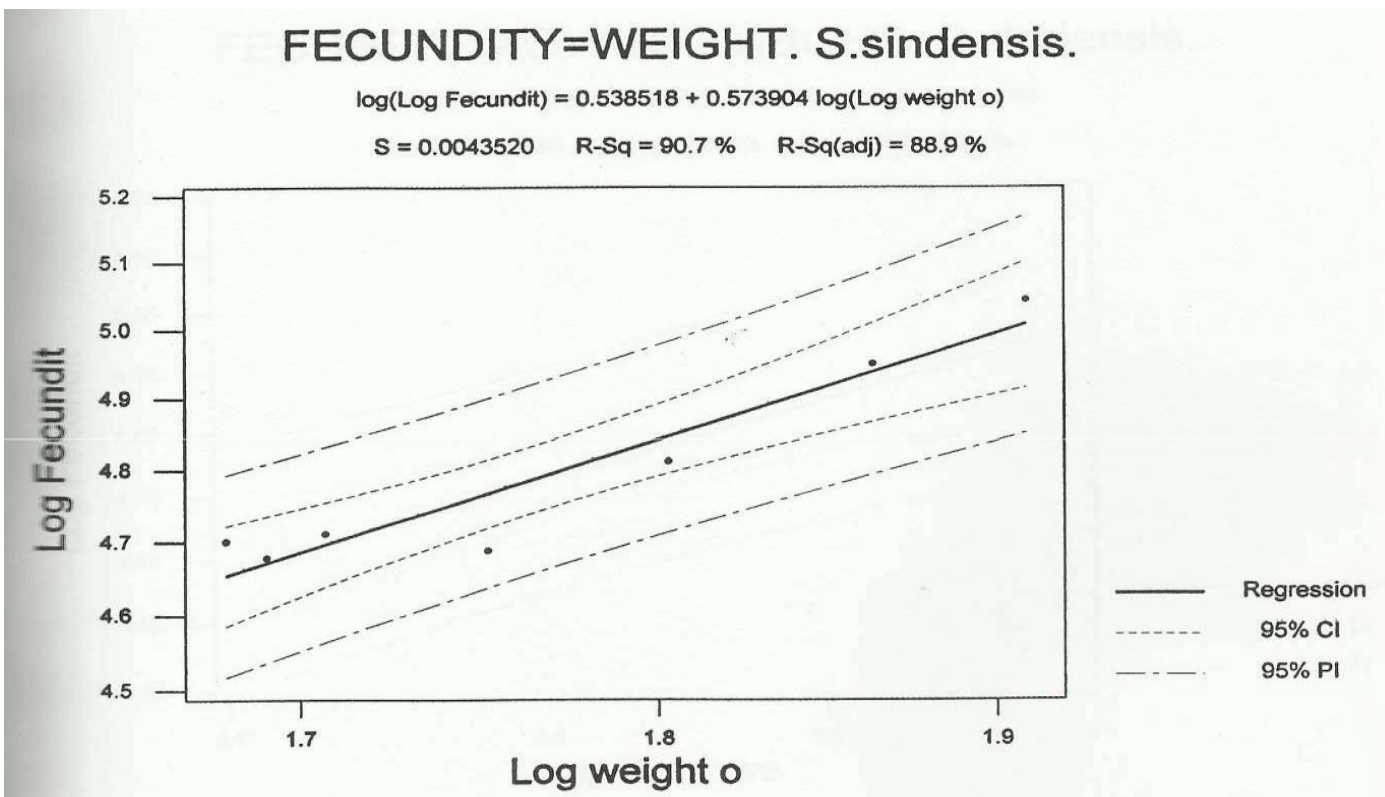

Fig. 2: $\log$ of body wt. 


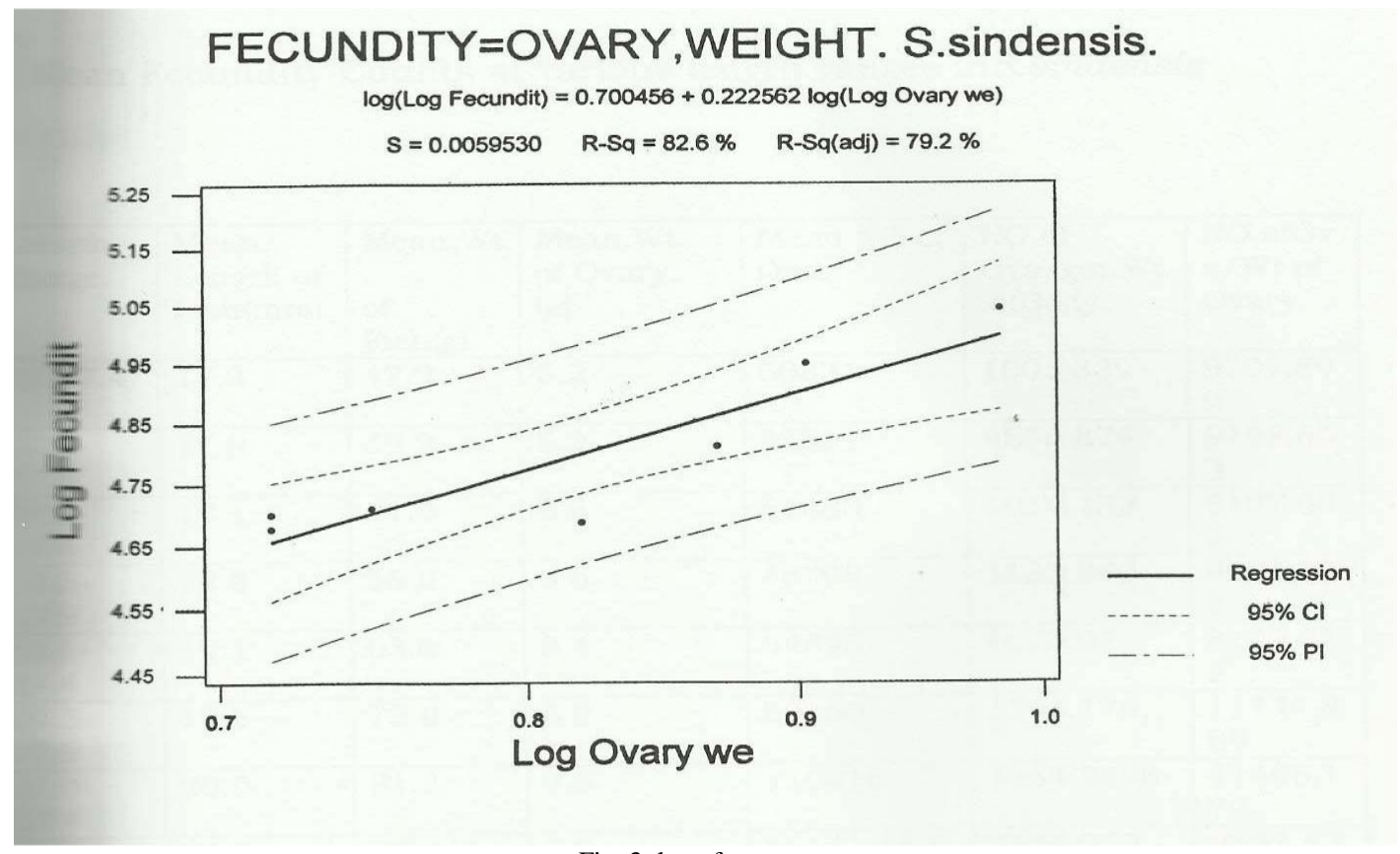

Fig. 3: $\log$ of ovary wt.

\section{Results and discussion}

The ovaries of 37 mature Sardinella sindensis stages (IV- V1) obtained from fish measuring $17.00 \mathrm{~mm}$ to $20.4 \mathrm{~mm}$ TL (Total length) and $47.9 \mathrm{gm}$ to $81.2 \mathrm{gm}$ weight were considered for the study of fecundity, it was estimated in relation to several variable size. T.L(total length) of fish, body weight of fish and ovary weight, and details, Mean fecundity at various length ranges are given in (Tab. 1) It is seen from the sample that the left ovary which is slightly larger than that of right. The number of ova depending on the differences in size. The fecundity of Oil Sardine, S. longiceps was estimated as 75,000 eggs calculate by [11].Therefore it may be mentioned here that the fecundity is generally proportional to the size (length) and weight of the fish, (Fig. 1, $2 \&$ 3.). The mean fecundity calculated to be 66151 the minimum and maximum being, 47521 and 110876 from the fish measuring $17.5 \mathrm{~mm}$ T.L and $20.4 \mathrm{~mm}$, T.L respectively. The number of ova/gm body weight and ovary weight is determined to be 2425 and 9537 were respectively (Tab. 1; Fig. 1, 2 \& 3). The gonads were two lobes the right (smaller) and the left (larger). The right lobe is less fecundity from then that of left lobe. On the basis of this details the total ova for an ovary weighing $6.8 \mathrm{gm}$ was estimated as 66151 of $S$. sindensis from the Karachi coast. [17, 18] Correlated the fish weight and fecundity and found straight line relationship between fish weight and fecundity. The findings of the present work are in agreement with their observations and it also reveals that the mean production per gram of fish decreased with higher weight grouping of fishes.

In Sardinella sindensis the fecundity is more closely related to fish length than fish weight. Similar views are expressed by [18] in Schizothorax richardsonie and [19] in Lasio gonius. This study will contribute valuable knowledge needed for fisheries management and aquaculture of Sardinella sindensis by increasing the knowledge of reproductive biology of Sardinella sindensis

\section{Acknowledgements}

My sincere gratitude is extended to the staff members and fellow colleagues of Department of Zoology (Dehli Govt. Science College, Hussain Abad), Department of Zoology (University of Karachi) and Department of Zoology (Sir Syed Govt. Girls College, Nazim Abad), Karachi.

\section{References}

[1] BALAN, V. Some observation the shoaling behaviour of Oil sardine Sardinella longiceps Val. Indian J. Fish, 8(1) (1961): 206-221. 
[2] HORNELL, J. Report on the results of a fishry cruise along the Malabar Coast and to the Laccadive Islands in 1908. Madras Fish. Bull. 4(4). (1910):71-126.

[3] HICKLING, C. F. The fecundity of the herring of the southrn North Sea. J.mar.biol.Ass. U. K. N. S., 24(2) (1949): 619-32.

[4] LEHMAN, B. A. Fecundity of Hudson River Shad. Res Rep. U.S. Fish. Wild life. Service. (1953). Pp 33.

[5] DAVIES, D. H. The South African pilchard (Sardinops ocellata) determined by ova-diameter measurements. Calif.Dept. Fish and Game.Fish Bull. 42(1956): 1-49.

[6] FULTON, T. W. The comparative fecundity of sea fishes.Fisheries Board of Scotland.9th Annual Report 3(1891): 243-268.

[7] El-Sayed, A. M. Life cycle and fecundity of rabbit fish, Siganus canaliculatus (Teleostei; Siganidae) in the Arabian Gulf. Oebalia., xx: (1994). 79-88

[8] KHAN, M. A. \& AMTYAZ. Studies on the fecundity \& Sex ratio of the Saddle grunt fish Pomadasys maculatum (Bloch, 1797), (Family: Pomadasyidae) from Karachi coast. Int. J.Biol. Biotech. 1(1) (2004): 111-115.

[9] AL-NAHDI, A., AL-MARZOUQI, A., JAYABALAN, N. AND AL-HABSI, S. Maturation and spawning of the small spotted grunt Pomadasys commersonnii (Lacepede, 1801) in the Arabian Sea of Oman. Thalassas, 27(2010): 67-79.

[10] ADEBIYE, F. A. The sex ratio, gonadosomatic index, stages of gonadal development and fecundity of Sompat grunt, Pomadasys jubelini (Cuvier, 1830), Pakistan J. Zool. 45(1) (2013): 41-46.

[11] NAIR, R. V. AND CHIDAMBARAM, K. A review of the Indian oil sardine fishery. Proc.nat. Inst. Sci. India, 17 (1) (1951):71-85.

[12] Tsikliras, A. C. \& Anthonopoulou, E. Reproductive biology of round sardinella, Sardinella aurita in the North-Eastern Mediterranean. Scientia Marina, 70(2) (2006). 281-290.

[13] Mussalam, A. S., Rashid, A. A., Al-Shuaily, S. S. \& Ambu-Ali, A. A. Observation on the fecundity and Gonado-Somatic Index (GSI) of Omani -Indian Oil sardine Sardinella longiceps (Valenciennes, 1847). Pak. Jr. Bio. Sc. 9(4) (2006): 700-702.

[14] Bianchi, G. Field guide to the Commercial marine and brackish water species of Pakistan. FAO, Rome. (1985). Pp22.

[15] FISHER, W. \& BIANCHI, S. G. FAO species identification sheets for fishery purpose. Western Indian Ocean, vol-2, (1984). FAO, Rome.

[16] COCHRAN, W. G. Sampling techniques. John Wiley and Sons, New York. (2007).

[17] Malhotra, Y. R. Studies on the seasonal changes in the ovary of Schizothorax niger (Hechd) from Dal Lake in Kashmir. Jap. Jr. Icth., 17(1971): 110-116.

[18] Misra, M. Studies on fishery biology of Schizothorax richardsoni (Gray). An economically important food fish of Garhwal Himalayas. Phil. Res. Grahwal University Srinagar Garhwal. (1982)

[19] Joshi, S. N. and khanna, S. S. Relative fecundity of Cario gonius (Ham.) from Nanak Sagar reservoir. Jr. Indian food Sc., 57 (1980): $343-348$. 